\title{
Comparing the effect of the training of cognitive behavioral coping skills and mindfulness based relapse prevention in reducing the psychological symptoms of people with substance dependency under methadone maintenance treatment
}

\author{
Sajjad Basharpoor ${ }^{1}$, Fariba Maghsoud ${ }^{2}$, Fazeleh Heidari $^{3}$ \\ 1-Associate Professor, Department of Psychology, University of Mohaghegh Ardabili, Ardabil, Iran (Corresponding \\ Author). ORCID: 0000-0002-2920-2605 E-mail: basahrpoor_sajjad@yahoo.com \\ 2- MA in Psychology, Department of Psychology, University of Mohaghegh Ardabili, Ardabil, Iran. ORCID: 0000- \\ 0002-3915-3800 \\ 3- PhD Student in Psychology, Department of Psychology, University of Mohaghegh Ardabil, Ardabil, Iran. \\ ORCID: 0000-0001-7501-5758
}

Received: 08/01/2019

Accepted: 11/03/2019

\begin{abstract}
Introduction: Psychological interventions are the one of requirements for effective treatment of substance users during abstinence period.

Aim: The aim of this study was comparing the effectiveness of the training of cognitive behavioral coping skills and mindfulness based relapse prevention in reducing psychological symptoms of people with substance dependency under methadone maintenance treatment.

Method: This study was conducted via experimental method with a pretest-posttest design and a control group. People with substance dependency referring to Ardabil centers of addiction treatment in the second half of 2017 comprised statistical population. The sample was sixty people, selected by cluster sampling and was assigned randomly to three 20 member groups of cognitive-behavioral coping skills; mindfulness based relapse prevention and control group. SCL-90-R was used to gather data in two pretest and posttest stages. The collected data were analyzed by multivariate covariance and bonferrony posthoc test.

Results: The results showed that there are significant differences between the scores mean of three groups in the variables of somatic complaints, depression, aggression and psychosis. The results of boferrony test also showed that there are not significant differences between two experimental groups in somatic complaints, depression and aggression. But, the mindfulnessbased relapse prevention alone was effective on reducing the psychosis.

Conclusion: The results of this study indicate that the using of cognitive-behavioral coping skills training and mindfulness-based relapse prevention can be useful psychological intervention for reducing psychological symptoms of people with substance dependency.
\end{abstract}

Keywords: Cognitive-behavioral coping skills, Mindfulness based relapse prevention, Psychological symptoms, Substance dependency

\footnotetext{
How to cite this article : Basharpoor S, Maghsoud F, Heidari F. Comparing the effect of the training of cognitive behavioral coping skills and mindfulness based relapse prevention in reducing the psychological symptoms of people with substance dependency under methadone maintenance treatment. Shenakht Journal of Psychology and Psychiatry. 2019; 6 (2): 102-115 .URL :http://shenakht.muk.ac.ir/article-1-313fa.pdf
}

Copyright (C) 2018 the Author (s). Published by Kurdistan University of Medical Sciences. This is an open access article distributed under the terms of the Creative Commons Attribution-Non Commercial License 4.0 (CCBY-NC), where it is permissible to download, share, remix, transform, and buildup the work provided it is properly cited. The work cannot be used commercially without permission from the journal. 


\section{مقايسهى تأثير آموزش مهارتهاى مقابله شناختىرفتارى و برنامه ييشكيرى از عود مبتنى بر ذهن آكاهى در كاهش علائم روانشناختى افراد وابسته به مواد تحت درومان مان نكهدار نده با متادون}

سجاد بشريور'، فريبا مقصود'، فاضله حيدرى ا. ادانشيار، گروه روانشناسى، دانشخاه محقق اردبيل، اردبيل، ايران (مولف مسئول). ايميل: basahrpoor_sajjad@yahoo.com

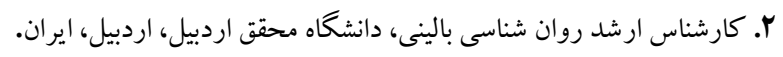

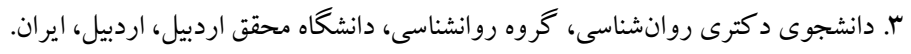
هدف: هدف اين مطالعه مقايسه تأثير آموزش مهارتهاى مقابلهى شناختى-رفتارى و برنامه ييشخيرى از عود مبتنى بر ذهن آكاهى بر

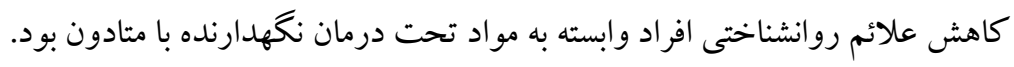
روش: اين بزوهش به روش آزمايشى و با طرح بيش آزمونيس آزمون با گروه كنترل انجام گرفت. جامعه آمارى شامل كليه افراد

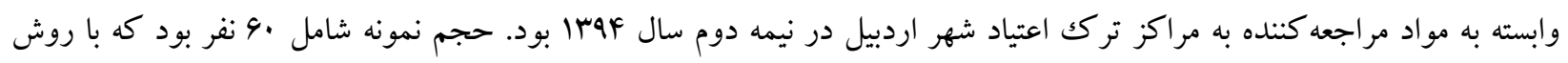

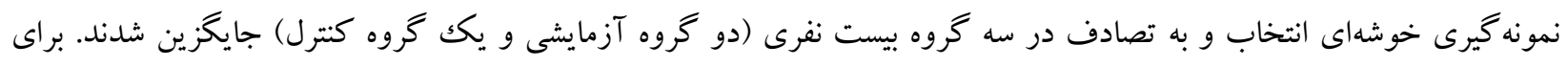

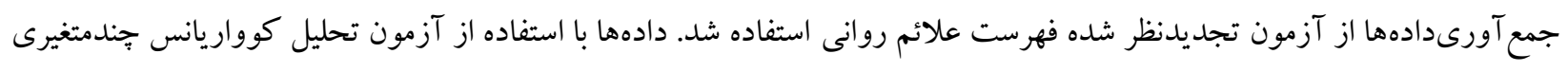
و آزمون تعقيبى بنفرونى تحليل شد.

يافته ها: نتايج نشان داد كه تفاوت آمارى معنىدارى بين ميانگين نمرات پس آزمون سه گروه در متغيرهاى شكايات جسمانى،

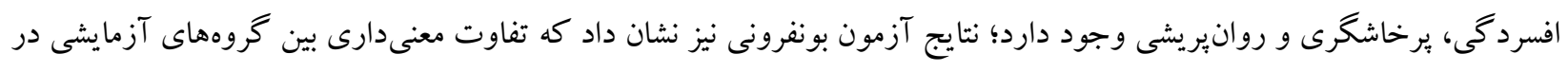

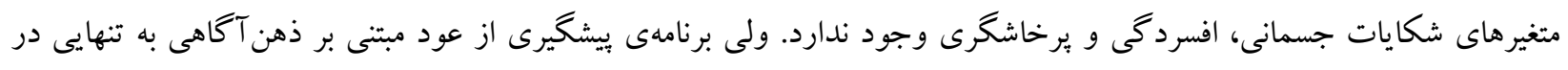
كاهش روان يريشى مؤثر بوده است.

نتيجه كيرى: نتايج اين مطالعه نشان مىدهد كه استفاده از روشهاى آموزش مهارتهاى مقابله شناختى رفتارى و ويشخيرى از عود مبتنى بر ذهن آكاهى مى تواند مداخله روانشناختى مفيدى براى كاهش علايم روانشناختى افراد وابسته به مواد باشد. كليد وازهها: مهارتهاى مقابله شناختىرفتارى، يُشگيرى از عود مبتنى بر ذهن آكاهى، وابستخى به مو اد 
شود (فر گوسن و هاروود"'، 199V؛؛ نيو كمبٍ و بنتلر"'، .$(1991$ يكى از مؤثرترين مداخلاتى كه براى وابستكى به مواد

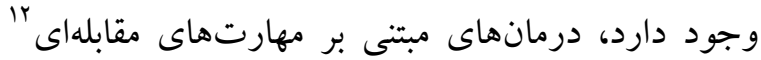

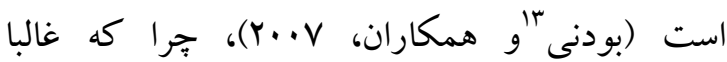
مصرف كنند گان مواد نقصهايى در مهارتهاى مقابلهاى

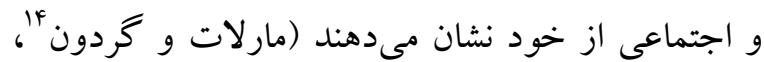
.191). فرايند مقابله به تلاشهاى شناختى و رفتارى شخص براى مديريت شرايط در جهت تسلط، كاهش و تحمل استرس اشاره دارد و جنين تصور مىشود كه ناتوانى در مقابلهى ساز كارانه با عوامل تنشزا نقش "يررنكى در مصرف مشكل ساز مواد و الكل داشته باشد

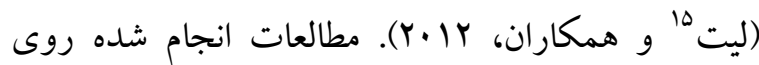
فرايند مقابله طى •r سال اخير نشان مىدهد كه اثرات منفى حوادث تنشزاى زندگى را مىتوان با استفاده از مهارتهاى مقابلهاى مقتضى تعديل نمود (بيو كايرتز 'إن

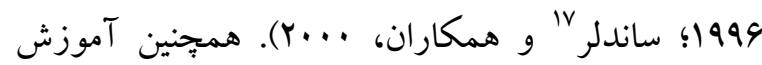
مهارتهاى مقابلهى شناختىرفتارى با كاهش سطوح

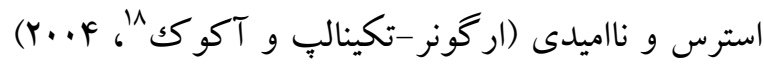
و آشفتكى (ريجتتاريكك و مكك گيليكودى

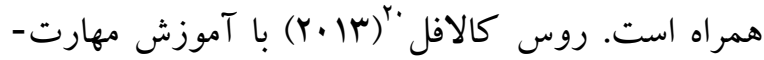
هاى اجتماعى شناختىرفتارى بر گروهى از بيماران سريايى اسكيزوفرنى نشان دادند كه آزمودنىهاى گرووه
مقلدمه مطالعات همه گيرشناسى همايندى آشفتكى روانشناختى' و مصرف مواد را شناسايى كردهاند (كانوى 'و همكاران،

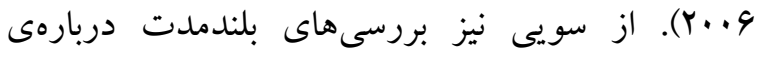
سلامت روانى و مصرف مواد بسيار نادر بوده و اغلب

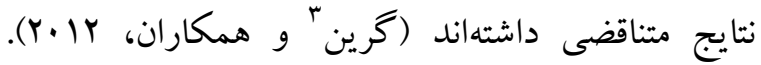
برخى از اين مطالعات، نشان دادهاند كه شروع زودهنگام مصرف مواد، آشفتخى روانى بعدى را بيشبينى مى كند؛ اما آشفتخى روانشناختى بيشبينى كنندهى مصرف مو مواد

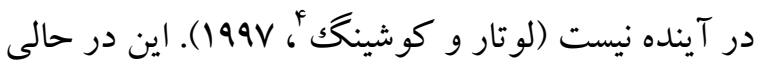
است كه آشفتخى روانشناختى دوران بلوغ، مصرف مواد را بيشبينى مى كند و در اين خط سير، مصرف مواد بيشبينى كنندهى آشفتكى روانشناختى بعدى است استى

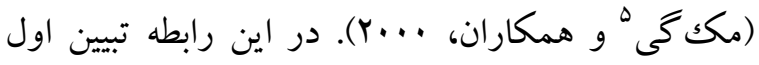
اين است كه افراد به اين دليل به مصرف مواد روى مى آورند تا علائم روانشناختى خود را تسكين دهند

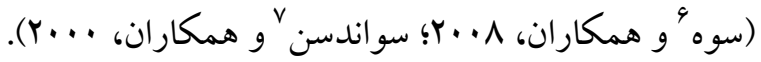
استدلال ديخر اين است كه مصرف مواد منجر به آشفتكى روانشناختى مى گردد (كرانت و همكاران،

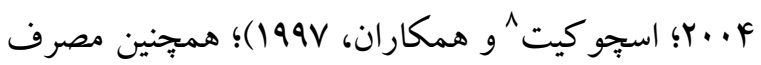
مواد مىتواند سبب علائم افسردگى و اضطراب شود

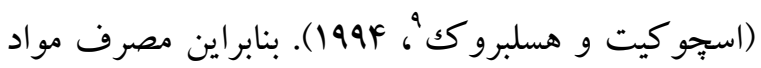
مى تواند در دراز مدت منجر به آشفتخىهاى روانشناختى

${ }^{10}$. Fergusson \& Horwood

${ }^{11}$. Newcomb and Bentler

12 . Copings skills

${ }^{13}$. Budney

${ }^{14}$. Marlatt \& Gordon

${ }^{15}$. Litt

${ }^{16}$. Boekaerts

17. Sandler

${ }^{18}$. Erguner-Tekinalp \& Akkok

19 . Rychtarik \& McGillicuddy

${ }^{20}$. Rus-Calafell

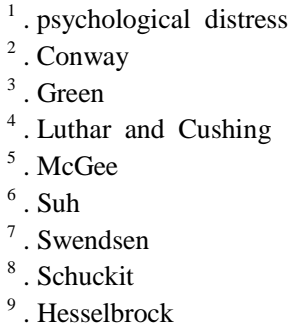


دو دهه اخير مربوط به ييشخيرى از عود به عنوان درمانى

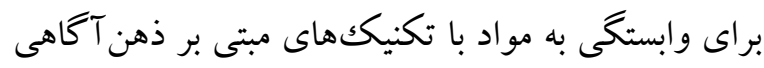
تلفيق شدهاند و برنامه بيشگيرى از عود مبتنى بر ذهن-

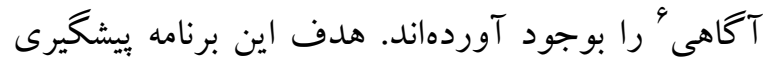
ايجاد آكاهى و يذّيرش افكار، احساسات درونى و بيرونى بـى

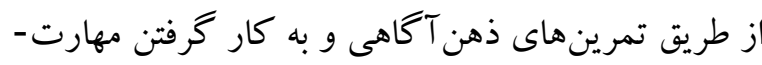
هاى ذهن آكاهى به عنوان يكك راهبرد مقابلهاى مؤثر در رويارويى با موقعيتهاى برخطر است. باون و همكاران

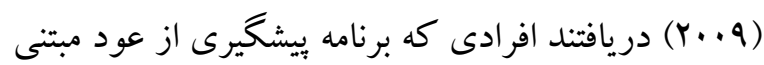
بر ذهن آكاهى را دريافت مى كنند به دنبال درمان، سطح ولع مصرف كمترى كزارش مى كنند. نتايج مطالعه ويتكيويتز و همكاران (r|r) نشان داد كاهش ولع مصرف به دنبال درمان بيشخيرى از عود مبتنى بر ذهن - روان آكاهى تغييرى است كه در يذيرش، آكاهى و نخرش

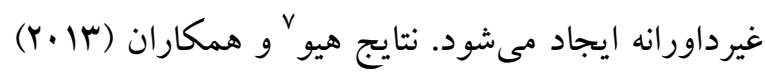
نيز نشان داد آزمودنىهاى معتاد داراى تحمل آشفتگى بايين كه برنامه يِشخيرى از عود مبتنى بر ذهن آكاهى دريافت كردند، نسبت به آزمودنىهاى داراى تحمل آشفتكى بايين كه درمان معمولى مصرف مواد را دريافت كردند، كاهش معنىدارى در بيامدهاى منفى مربوط به

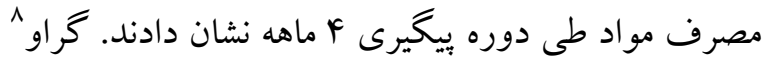

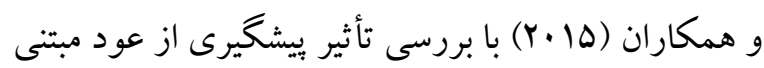
بر ذهن آكاهى نشان دادند در آزمودنىهايى كه اين درمان را دريافت كرده بودند، مدت زمانى كه براى تمرينهاى ذهن آكاهى صرف مى كردند بعد از دوره درمانى افزايش يافته بود و اين افزايش با مصرف يايين
آزمايش بهبودىهاى معنىدارى در علائم آسيبشناسى روانى، آشفتكى اجتماعى، شناخت اجتماعى، كناره گيرى اجتماعى، ارتباط ميان فردى و كيفيت زندگى در مقايسه

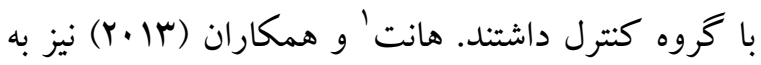
اين نتيجه رسيدند كه فراوانى و كيفيت استفاده از مهارت هاى شناختىرفتارى بر بيامدهاى درمانى افسردگى نقش واسطهاى دارد و باعث اثربخشى بيشتر درمان

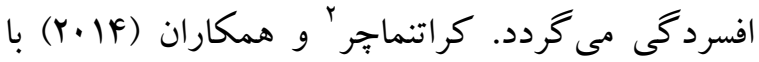
بررسى ارتباط راهبردهاى مقابلهاى با سلامت روانى در نوجوانان داراى والدين مبتلا به سرطان به اين نتيجه رسيدند كه بين ميزان استفاده از مهارتهاى مقابلهاى مسئلهدار و سلامت روانى اين كودكان ارتباط مثبت

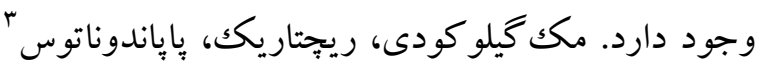
(Y.10) با مقايسه تأثير آموزش مهارتهاى مقابلهاى، برنامه تسهيل rا گامى و كنترل درمان تأخيرى ب براى والدين داراى نوجوانان مبتلا به سوء مصرف مواد نشان دادند كه آموزش مهارتهاى مقابلهاى، مهارت بيشترى در مقايسه با دو روش ديخر ايجاد مى كند. يافتهاى نوروبيولوزيكى از اين فرض حمايت مى كنند كه مراقبه ذهن آكاهى نيز مىتواند اجبار براى مصرف و و تكانشورى افراد وابسته به مواد را كاهش دهد (مارلات،

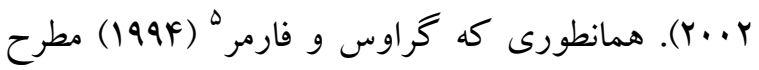
كردند در زمينه اعتيادها، ذهن آكاهى به معنى آكاه شدن از عوامل برانگيزاننده و محرك ولع مصرف و و انتخاب انجام كار ديخرى است كه مىتواند ولع مصرف را بهبود بخشد يا از آن بيشخيرى نمايد. در اين راستا بيزوهشهاى

${ }^{6}$. Mindfulness based relapse prevention

7 . Hsu

1. Hundt

2. Krattenmacher

3. McGillicuddy

${ }^{4}$. delayed treatment control

${ }^{8}$. Grow

${ }^{5}$. Groves and Farmer 
براى جمع آورى اطلاعات، ابتدا ليست تمامى مراكز ترك

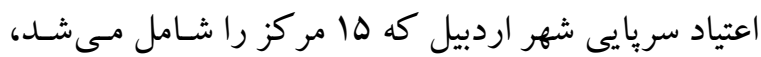
تهيه و سبس يكك مركز از بين آنها بـه روش نمونسه كيـرى خوشهاى انتخاب و بِ از مر اجعه به مركز مربوطه (مركز تركك اعتياد بامداد) تمامى يروندههاى مر اجعين آن مراكز در دسترس قرا گرفت. سبِ از بين آنها تعداد •9 يرونـده به روش تصادفى ساده انتخاب و طى تماس تلفنى از آنها براى مشاركت در يثوهش دعوت به عمل آمد. در مرحله

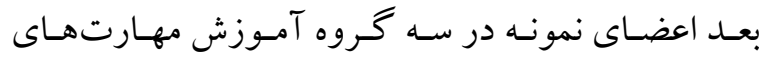

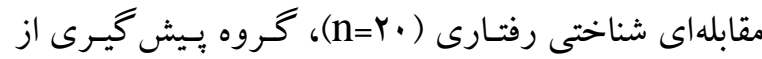

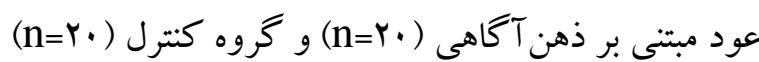
به تصادف جايگزين شدند. سُّ آزمون تجديدنظر شـده

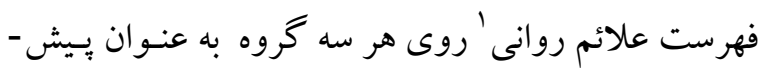
آزمـون اجــراو در مرحلـه بعـــ مـداخلات درمـانى روى كروههاى آزمايشى اجرا شد و در نهايت هر سه گ خروه بـــ

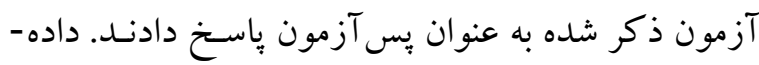

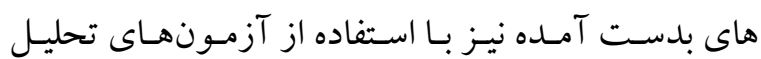
كواريانس جند متغيرى، يـك متغيـرى و آزمـون تعقيبى بنفرونى تجزيه و تحليل شد.

ابز ار آزمون تججديد نظر شلده فهرست علائم روانى •q سؤالى:

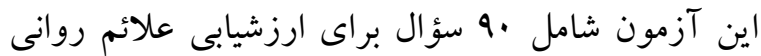
است كه شدت نشانها و شكايتهاى معمول روانى را مىسنجد. براى هر ماده يرسشنامه ينج گزينه هيج (نمره

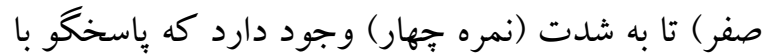
در نظر كرفتن اينكه جهه ميزان اين مشكل رادر طول هفته كذشته تا به امروز تجربه كرده است كزينه مورد نظرخد
الكل و هر داروى ديخر و كاهش ولع مصرف در بيگيرى هاى Y و F ماهه همر اه بود. نتايج موجود نشان مىدهند كه اغلب افراد وابسته به مواد در مرحله مسموميتزدايى آشفتخى روان شناختى بالايى تجربه مى كنند كه مى تو اند عامل مهمى در شكست يرهيز و عود اعتياد به حساب بيايد. همجِين نتايج نشان مىدهند كه مهارتهاى شناختىرفتارى و آموزش برنامه يشخيرى از عود مبتنى بر ذهن آكاهى با بيامدهاى مثبت درمان

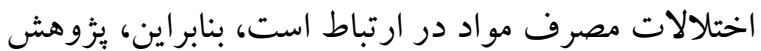
حاضر با هدف مقايسه تأثير آموزش مهارتهاى مقابلهى

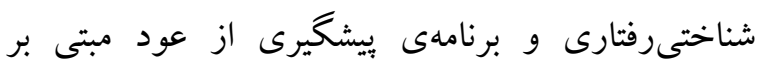
ذهن آكاهى بر كاهش علائم روانشناختى افراد وابسته به مواد انجام كرفت؟

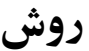

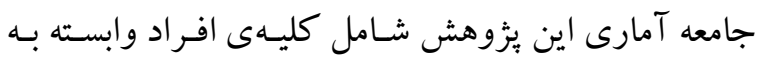
مواد مراجعه كننده بـه مراكز تـرك اعتيـاد سـريايى شـهر اردبيل در نيمسه دوم سـال موسا بـود. حجـم نمونسه مـورد بررسى ،و نفر بود كه به شيوهى تصـادفى خوشـهاى جنــ

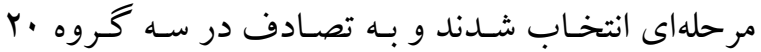
نفرى شامل دو گروه آزمايش و يـك گـروه كنتـرل قـرار كرفتند. عدم ابتلاء به بيمارىهاى جسمانى، داشـن سـطح

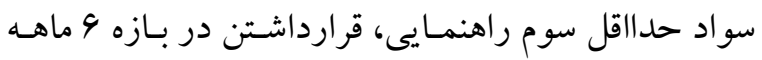
درمان با متادون از ملاكهاى ورود آزمودنى ها به مطالعسه و غيبت بيش از سه جلسه در مداخلات و عــدم تمايـل بــراى همكارى در بزوهش نيز ملاكهاى خـروج آزمـودنىهـا از مطالعه حاضر بود. روش يـرٔوهش در ايـن بررسى از نـوع

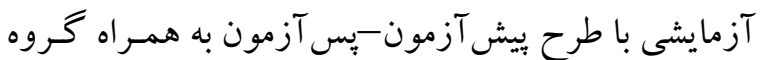
كنترل بود.

\footnotetext{
${ }^{1}$. Symptom Checklist-90-Revised
} 
مقابله اى شناختى رفتارى طراحى شده طى 1 جلسه

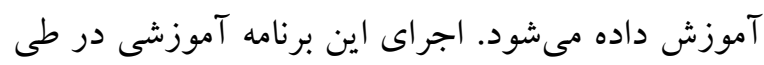
F أ هفته و در هر هفته Y جلسه يكك ساعته به شرح زير انجام مى گيرد.

جدول 1 محتواى جلسات برنامه آموزش مهارتهاى مقابله شناختى

جلسه اول آشنايى و برقرارى ارتباط، اجراى ويش آزمون، بيان

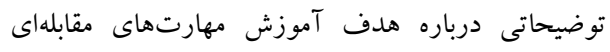
شناختى رفتارى جلسه دوم آموزش مهارت خود آكاهى

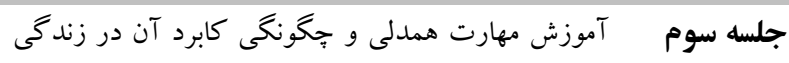

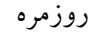

\begin{tabular}{|c|c|}
\hline آموزش مهارت برقرارى ارتباط مؤثر & جلسه جهارم \\
\hline آموزش مهارت برقرارى ارتباط بين فردى & جلسه ينجم \\
\hline آموزش مهارت هاى افزايش عزت نفس & جلسه ششم \\
\hline آموزش مهارت مديريت بر هيجانات & جلسه هفتم \\
\hline آبا اسوزش مهارت مديريت استرس، كمكك به شناسايى استرس روى زندى و فهميدن اهميت و مقابله & جلسه هشتم \\
\hline
\end{tabular}

r. برنامه بيش گيرى از عود مبتنى بر ذهن آكاهى: برنامه يشخيرى از عود مبتنى بر ذهن آكاهى يك بر برنامه

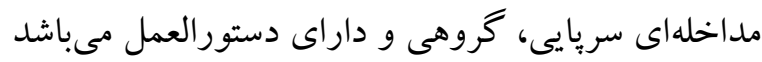

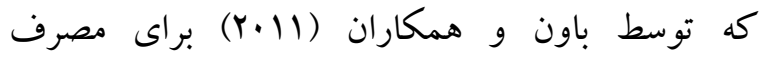
مشكلزاى مواد ساخته و ارزيابى شده است. اين برنامه تكنيك هاى سنتى بيشخيرى از عود شناختى رفتارى را با

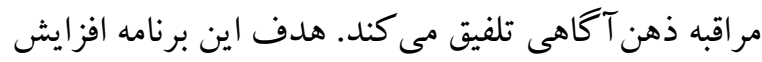
آكًاهى و بذيرش افكار، احساسات درونى و بيرونى از طريق تمرين مر اقبه ذهن آكاهى و استفاده از اين مهارتها

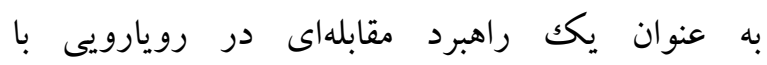
موقعيت هاى برخطر براى عود مىباشد
را مشخص مى كند. اين برسشنامه داراى 9 بعد و r شاخص است. ابعاد ه گانه اين آزمون عبارتاند از ا. شكايتهاى جسمانى، r. وسواس - اجبار، ب. حساسيت

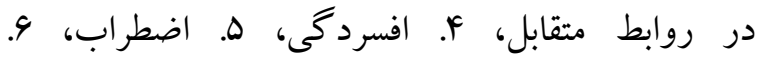

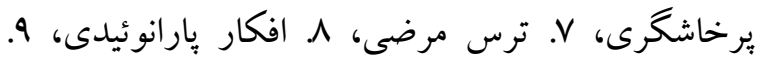
روانيريشى. بايايى اين آزمون به روش باز آزمايى بين

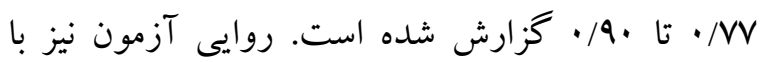
انجام بررسىهايى كه بر روى گروههاى بيماران روانى، بيماران جسمى و افرادى كه تحت شرايط ير فشار روانى بودهاند انجام شده رضايت بخش كزارش شده است

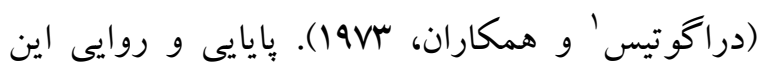
آزمون در ايران قابل قبول بوده است. دراگوتيس و همكاران (19V9) ضرايب همبستكى ابعاد مختلف اين

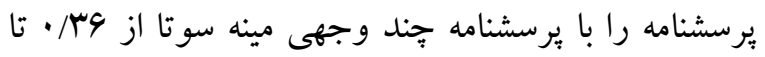

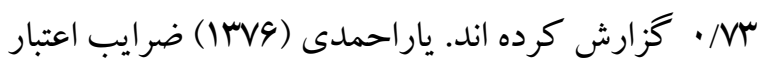

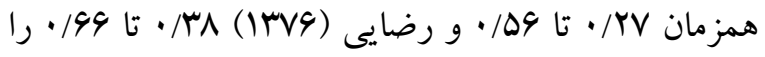
بدست آوردند. ثبات درونى آن از VV/ براى بعد روان بريشى تا •و/، براى بعد افسردگى گزارش شده است.

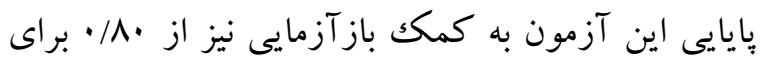
بعد شكايتهاى جسمانى تا •9/. براى افكار يارانوئيدى

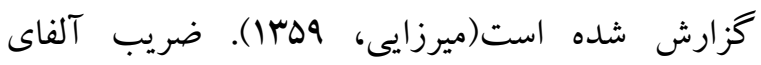
كرونباخ اين آزمون در يزوهش حاضر نيز در دامنه ایى از

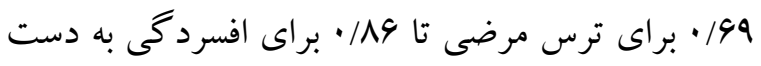

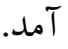
مداخلات درمانى ا.آموزش مهارتهاى مقابله اى شناختى رفتارى: برنامه

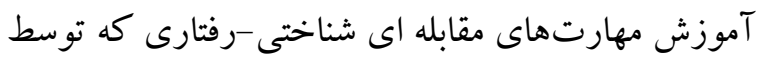

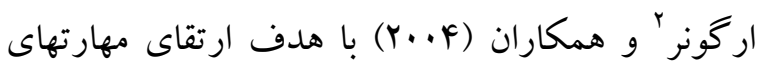

\footnotetext{
1. Deragotis

2 . Erguner-Tekinalp \& Akkok
} 
بر ذهن آكاهى (Yس/ I) · م/ه سال بود. از لحاظ وضعيت اقتصادى - اجتماعى در كروه آموزش مهارتهاى مقابلهاى شناختى رفتارى V نفر (ها درصد) وضعيت خود را ضعيف، 9 نفر (r) درصد) متوسط، F نفر ( •Y درصد) خوب و بنفر نيز عالى گزارش كردند. در گروه بيشخيرى از عود مبتنى بر ذهن آكاهى و نفر (·س درصد)، وضعيت خود را ضعيف، F نفر

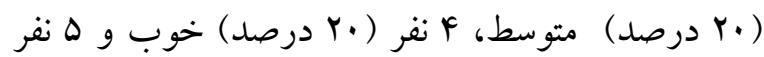

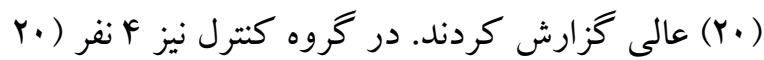
درصد) وضعيت خود را ضعيف، $\wedge$ نفر (·F درصد) متوسط، س نفر (ها درصد) خوب و م نفر (ها درصد) نيز عالى كزارش كردند.
بر اساس ساختار برنامه كاهش استرس مبتنى بر ذهن آكاهى' و شناخت درمانى مبتنى بر ذهن آكاهى '؛ برنامه بيشگيرى از عود مبتنى بر ذهن آكاهى نيز 1 جلسه هفتخى كروه درمانى Y ساعته مىباشد. گروه شركت كنند گان درباره بيشخيرى از عود با هم بحث كرده و تكنيكهاى ذهن آكاهى را تمرين مى كنند. بحثهاى كروهى شامل موضوعاتى نظير يادآورى تمايل به هدايت خودكار بودن'، شناسايى محر ككهاى برانگيزان عود، ياد گيرى آكاه بودن از لحظه حال، حضو ذهن داشتن در طول افكار و تجربيات خوشايند و ناخوشايند، ترويج يك نُخرش يذيرش و كار روى موانع تمرين (باون، جاولا و

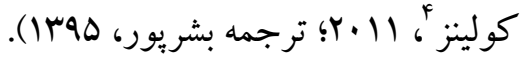

\begin{tabular}{|c|c|}
\hline هدايت خود كار و عود & جلسه اول \\
\hline آكاهى از محرككهاى برانگيزان و ولع مصرف & 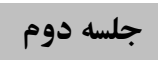 \\
\hline ذهن آكاهى در زندگى روزمره & جلسه سوم \\
\hline ذهن آكاهى در موقعيتهاى يرخطر & جلسه جهارم \\
\hline 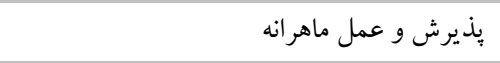 & 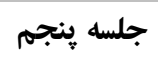 \\
\hline مشاهده افكار به عنوان افكار نه واقعيات & جلسه ششم \\
\hline خود مر اقبتى و تعادل در سبك زندگى & 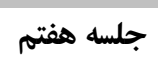 \\
\hline حمايتهاى اجتماعى و تمرينهاى مستمر & جلسه هشتم \\
\hline
\end{tabular}

يافتهها

تعداد •4 آزمودنى در سه گروه .Y نفرى در اين مطالعه شركت داشتند كه ميانگين (انحراف معيار) سنى آزمودنىهاى گروه آموزش مهارتهاى مقابله شناختى رفتارى (TD/

\footnotetext{
1. Mindfulness based stress reduction (MBRS)

${ }^{2}$. mindfulness based cognitive therapy (MBCT)

${ }^{3}$. automatic pilot

${ }^{4}$. Bowen, Chawla \& Collins
} 


\begin{tabular}{|c|c|c|c|c|c|c|c|}
\hline \multicolumn{2}{|c|}{ كنترل } & \multicolumn{2}{|c|}{ برنامهى بيشغيرى از عود } & \multicolumn{2}{|c|}{ آموزش مقابله شناختىرفتارى } & \multirow{3}{*}{ شاخص آمارى } & \multirow{3}{*}{ متغير } \\
\hline 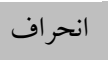 & ميانگين & 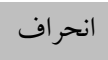 & 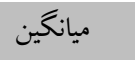 & انحر اف استاندارد & 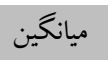 & & \\
\hline استاندارد & & استاندارد & & & & & \\
\hline $1 \cdot / 99$ & TF/O. & $11 / 11$ & YN/Yr & $Q / F \Delta$ & rA/VA & بيش آزمون & \multirow[t]{2}{*}{ شكايات جسمانى } \\
\hline$F / \Delta 1$ & $r \wedge / q I$ & $r / 9 r$ & $|r /| \Lambda$ & Y/A & $\mid \Delta / M$ & 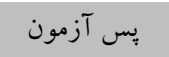 & \\
\hline Q/VY & YY/rD & 1.194 & $r V / r q$ & Q/Tr & $r \Delta / \Lambda$. & 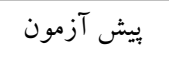 & \multirow{2}{*}{ وسواس - واجبار } \\
\hline $1 \cdot / 11$ & $r \mu / \cdot$ & G/AM & $r \cdot / \Lambda \Lambda$ & rr/r & $r \cdot / M$ & 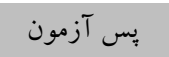 & \\
\hline$|r /| r$ & TG/TV & $1 r / 94$ & $r V / \Delta r$ & $1 \cdot / \Delta \Delta$ & $r \cdot 109$ & ي بيش آزمون & \multirow[t]{2}{*}{ افسردكى } \\
\hline$V / 9 \Delta$ & $r q / .$. & $r / N r$ & $V / \Delta F$ & $\varphi / l$. & $11 / 11$ & 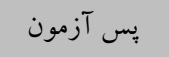 & \\
\hline N/Ar & س M/N & G/AV & $r Y / A D$ & $V / \Delta)$ & $r \mid / q r$ & بيش آزمون & \multirow{2}{*}{ روابط بين فردى در } \\
\hline$\Lambda / \Delta$ & $r r / l q$ & $Q / \Delta F$ & $\mid N / F$. & $\Delta / \& \Delta$ & $\mid r / F F$ & 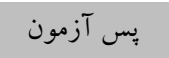 & \\
\hline $1 \cdot / \Delta F$ & $19 / F F$ & $q / 4 q$ & $r \Delta / F V$ & $\Lambda / v a$ & $Y F / 9 \Lambda$ & 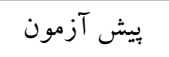 & \multirow[t]{2}{*}{ اضطراب } \\
\hline $9 / \Delta$. & $r \cdot / V \Delta$ & $r / 9 \Lambda$ & $I F / Y V$ & १/१९ & IV/FF & يس آزمون & \\
\hline$\Delta / \wedge q$ & $11 / \wedge$. & $\Delta / ৭ \Delta$ & $19 / \mathrm{Vr}$ & $q / r$. & $I r / v \Delta$ & ي بيش آزمون & \multirow[t]{2}{*}{ يرخاشكرى } \\
\hline G/Dr & $|N / F|$ & $F / T \wedge$ & $\Lambda / \cdot$ & r/lF & $V / 11$ & 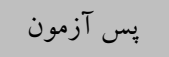 & \\
\hline $9 / \Delta r$ & $11 / \wedge \Delta$ & $\Delta / \Lambda \Gamma$ & $10 / 94$ & $F / 9 q$ & $\mid F / A F$ & 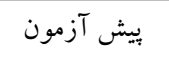 & \multirow[t]{2}{*}{ ترس مرضى } \\
\hline$\Delta / A r$ & $\mid f / \cdot \wedge$ & $9 / \pi q$ & $1 r / 94$ & $q / \cdot F$ & $|f /| \mid$ & 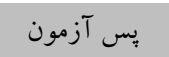 & \\
\hline $0 / 99$ & טr/rו & $g / F r$ & $\mathrm{~V} / \cdot \Delta$ & $F / 91$ & $I F / M$ & بيش آزمون & \multirow{2}{*}{ يارانوئيلى افكار } \\
\hline$\Delta / \Gamma \Lambda$ & $19 / 0$ & $9 / \cdot V$ & $\mid r / F \Delta$ & $V / T F$ & $1 r /$. & 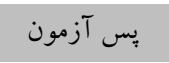 & \\
\hline $1 \cdot 19$ & $19 / A F$ & $\Lambda / r \Delta$ & rG/MT & $N / \Delta 1$ & rG/Tr & ي بيش آزمون & \multirow[t]{2}{*}{ 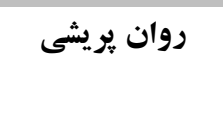 } \\
\hline$Q / V Y$ & IN/VD & $9 / 90$ & YI/AI & $1 . / 9 F$ & rY/94 & 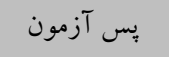 & \\
\hline $9 \cdot 1 \cdot v$ & $19 Y / A D$ & FY/Vq & $1 \wedge 9 / A V$ & $r q / \cdot F$ & $M N Y / V V$ & بيش آزمون & نمره كلى \\
\hline FN/Aq & $r l \cdot / k$. & $41 / 19$ & IrV/VD & r $/$ / & $\mid r Y / A \Delta$ & 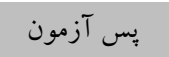 & \\
\hline
\end{tabular}

نتايج جدول ب ميانگين و انحراف معيار نمرات سه گروه در هر يكك از خرده مقياسهاى فهرست علايم •ه سوالى و نمره كلى آن را نشان مىدهد.

جدول \& نتايج آزمونهاى تحليل كوواريانس جند متغيرى

\begin{tabular}{|c|c|c|c|c|c|}
\hline مجذور اتا & معنى دارى & فراوانى & ارزش & نام آزمون & \multirow{5}{*}{ كروه } \\
\hline .19 &.$/ r$ & $r / Y$. & $1 / r$ & اثر بيلايى & \\
\hline$\cdot / N$ & $\% r$ & $r / v r$ & $\cdot / T V$ & لامبداى ويلكز & \\
\hline - /Ar & $\cdot / \cdot \cdot 1$ & $\Delta / N$ & $Q / T V$ & اثر هتلينك & \\
\hline$\cdot / 19$ &.$/ . .1$ & $1 Y / \Lambda q$ & N/qT & بزر گترين ريشهروى & \\
\hline
\end{tabular}


اين جدول مقدار لامبداي ويلكز نشان مىدهد كه TV درصد از تفاوتهاى بين سه گروه مربوط به اثر بخشى
جدول ب نتايج آزمونهاى جند متغيرى براى مقايسه ميانگين نمرات سه گروه در هر يك از خرده مقياس فهرست علايم ·9 سوالى را نشان مىدهد. مطابق نتايج

جدول ه نتايج تحليل كوواريانس جند متغيره جهت تعيين اثربخشى آموزشهاى ارائه شده

\begin{tabular}{|c|c|c|c|c|c|c|c|c|}
\hline آمارى توان & ميزان تأثير & معنى دارى & فراوانى & مجذورانكين & دراده & مجذمورع & متغير وابسته & منبع تغييرات \\
\hline.$/ . \Delta$ &.$/ \cdot 1$ & $\cdot / 9 \mathrm{~V}$ &.$\cdots 1$ & .1 .9 & 1 & $.1 \cdot 9$ & شكايات جسمانى & اثر ييش آزمون \\
\hline ( & $\cdot / 1 r$ & $\cdot / 1$ & Y/AV & YND/DY & 1 & $r \wedge \Delta / \Delta r$ & وسواس & \\
\hline.$/ 1$ & $\cdot / \cdot r$ & $\cdot / 4 q$ & $\cdot / 4 q$ & IN/AK & 1 & IN/AK & افسردگى & \\
\hline$\cdot / \cdot 1$ & $\cdot / \cdot 1$ & $\cdot / \Delta \mathrm{V}$ & ( & rr/A. & 1 & rr/A. & حساسيت & \\
\hline.$/ 1 F$ & $\cdot / \cdot F$ & - & $\cdot / \wedge \Delta$ & $G M / T F$ & 1 & GT/TF & اضطراب & \\
\hline$\cdot / \cdot V$ &.$/ \cdot 1$ & .194 & $\cdot / r Y$ & G/AF & 1 & G/AF & يرخاشگرى & \\
\hline$\cdot / \mathrm{IV}$ & $\cdot / \cdot \Delta$ & $\cdot \pi$. & $1 / .9$ & $90 / \cdot 1$ & 1 & $9 \Delta / \cdot 1$ & ترس مرضى & \\
\hline$\cdot / \cdot V$ & $\cdot \cdots \wedge$ & $\cdot 191$ & $\cdot / 1 \mathrm{~V}$ & $V / \mu F$ & 1 & $V / \mu F$ & افكار يارانويا & \\
\hline$\cdot / r V$ & r & .1 .9 & $r / 9 \Lambda$ & TFY/IG & 1 & YFT/IG & روان بريشى & \\
\hline$\cdot / 9 V$ & $\cdot / 01$ &.$/ \cdot 1$ & $1 \cdot / F F$ & GFF/VI & r & IYNQ/FT & شكايات جسمانى & عضويت كروهى \\
\hline$\cdot 1 \cdot \Delta$ & $\cdot \cdot r$ & $\cdot / 9 \mathrm{~V}$ & $\cdot / \cdot r$ & $r / 9 \Lambda$ & r & $\Delta / 9 V$ & وسواس & \\
\hline $1 / \cdot$ & $\cdot / \Lambda$ & $\cdot / \cdot \cdot 1$ & $F \cdot / A r$ & IDGT/FT & r & rIre/rq & افسرد گى & \\
\hline • &.$/ 10$ &.$/ 19$ & $1 / V 4$ & IYN/M & r & $r \Delta V / V V$ & حساسيت & \\
\hline$\cdot / I F$ & $\cdot / \cdot \Delta$ & $\cdot / \Delta \Delta$ & .191 & $F \Delta / 9 \Lambda$ & r & $91 / 44$ & اضطراب & \\
\hline$\cdot / \wedge \Delta$ & $\cdot / r q$ & $\cdot / \cdot v$ & $9 / F V$ & $199 / \pi V$ & r & MAY/vo & يرخاشگرى & \\
\hline .1 .9 & $\cdots v$ & . $/ 94$ & $\cdot / \cdot V$ & $r / r r$ & r & $\Lambda / F \Delta$ & ترس مرضى & \\
\hline$\cdot / \cdot \wedge$ & $\cdot / \cdot r$ & $\cdot / V \Delta$ & $\cdot / r \Lambda$ & $\mid r / \Delta \Delta$ & r & $r \Delta / 1$. & افكار يار انويا & \\
\hline$\cdot / \Delta r$ & 每/ & $.1 \cdot 0$ & $r / \cdot V$ & $r \Delta \cdot / 10$ & r & $\Delta \cdots / r$. & روان يريشى & \\
\hline
\end{tabular}

نتايج جدول ه نشان مىدهد كه بعد از كنترل اثرات بيش

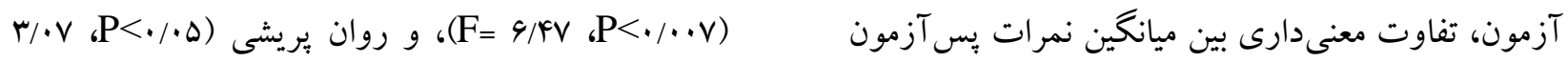

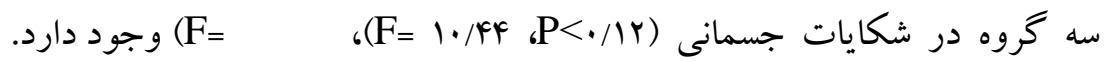

\begin{tabular}{|c|c|c|c|}
\hline كنترل & 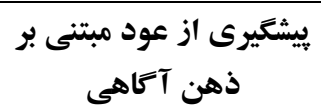 & كروها & متغير ها \\
\hline$-1 \Delta / \wedge \cdot(P<\cdot / \cdot .4)^{*}$ & $r / \cdot \Delta(p=1 / \cdot \cdot)$ & مهارت هاى مقابله شناختى رفتارى & شكايات جسمانى \\
\hline$-1 / / \Lambda \Delta(\mathrm{P}<\cdot / \cdot 4)^{*}$ & - & ييشگيرى از عود مبتنى بر ذهن آكاهى & \\
\hline- & - & كنترل & \\
\hline
\end{tabular}




\begin{tabular}{|c|c|c|c|}
\hline$-r \xi / r \cdot(P<\cdot / \cdot \cdot 1)^{*}$ & $r / F I(P=1 / \cdot \cdot)$ & مهارتهاى مقابله شناختى رفتارى & \multirow[t]{3}{*}{ افسردگى } \\
\hline$-Y \wedge / 9)(P<\cdot / \cdot \cdot 1)^{*}$ & - & ييشخيرى از عود مبتنى بر ذهن آكاهى & \\
\hline- & - & كنترل & \\
\hline$-9 / \wedge 9(\mathrm{P}<\cdot / \cdot \cdot 1)^{* *}$ & $-\cdot / / V(\mathrm{P}=1 / \cdot \cdot)$ & مهارتهاى مقابله شناختى رفتارى & \multirow[t]{3}{*}{ 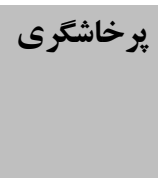 } \\
\hline$-9 / V)(P<\cdot / \cdot 1)^{*}$ & - & يِيشگيرى از عود مبتنى بر ذهن آكاهى & \\
\hline- & - & 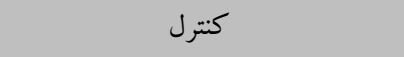 & \\
\hline $1 \cdot / 11(\mathrm{P}=\cdot / \cdot \wedge)$ & $-1 / \Delta 1(\mathrm{P}=1 / \cdot \cdot)$ & مهارتهاى مقابله شناختى رفتارى & \multirow[t]{3}{*}{ 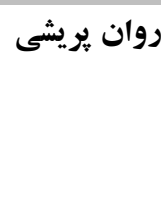 } \\
\hline$-11 / 9 r(P<\cdot / \cdot \Delta)^{*}$ & - & بيشخيرى از عود مبتنى بر ذهن آكاهى & \\
\hline- & - & كنترل & \\
\hline
\end{tabular}

دارى وجود نــارد.همجينين يافتـهـا نشـان مس دهـد كـه

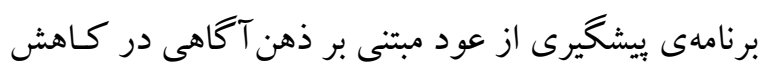

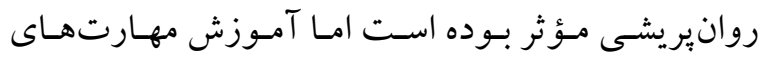

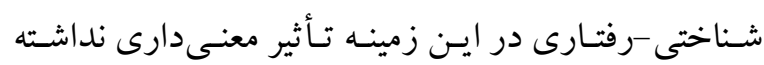

نتايج جدول و نشان مىدهد كه برنامـه يِيشـيرى از عـود

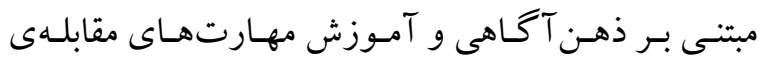
شناختى -رفتارى در كاهش شكايات جسمانى، افسردگى و يرخاشخرى تفاوت معنىدارى با گروه كنترل دارند ولى لى در ميزان اثربخشى ايسن دو روش درمـانى، تفـاوت معنى -

\begin{tabular}{|c|c|c|c|c|c|c|}
\hline ضريب اتا & معنى سطارى & فراوانى & مجذانكين & آزادى درجه & مجذوروات & نمره \\
\hline.$/ 4$ &.$/ 10$ & $r / \cdot F$ & $r V r \cdot / r \cdot$ & 1 & $r V r \cdot / r$. & اثرييش آزمون \\
\hline 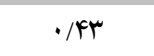 &.$/ .1$ & $r M / W$ & raDVG/NG & r & VQIOH/AG & اثرعضويت كروهى \\
\hline
\end{tabular}

با توجه به اين كه مطالعات نشان داده است بين آشفتكى روانشناختى و مصرف مواد همايندى وجود داشته و مصرف مواد مىتواند سبب علائم افسردگى و اضطراب شود و از سويى ديخر از آنجا كه نقش مؤثر راهبردهاى

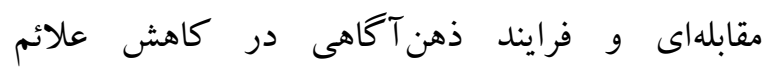
روانشناختى و مصرف مواد به اثبات رسيده است، مطالعه حاضر با هدف مقايسهى اثربخشى آموزش مهارتهاى

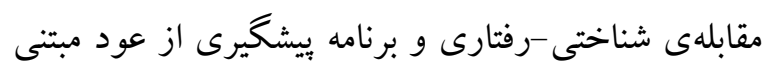
بر ذهن آكًاهى بر كاهش علائم روانشناختى در افراد

$$
\text { وابسته به مواد اجرا شد. }
$$

نتايج جدول V نشان مى دهد كه بعد از كنترل اثر بيش آزمون تفاوت معنى دارى بين ميانگين نمره كلى دو گروه هر يس آزمون نمره كلى آزمون فهرست علايم

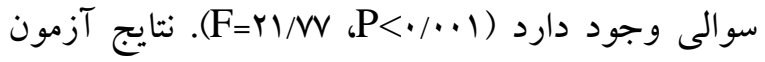
بنفرونى براى مقايسه دو به دوى ميانگين سه گروه نيز

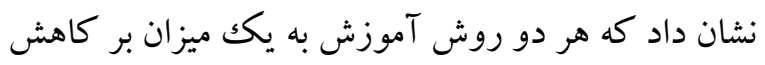
علايم روان شناختى افراد وابسته به مو اد مؤثر بودند. 
مطالعـات انجـام شــده هماينــدى علائسم روانشــاختى و مصرف مواد را مورد تأييد قرار داده (كانوى و همكاران،

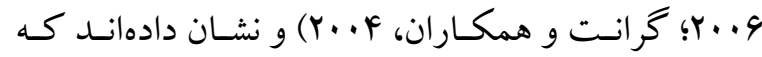
مصرف مـواد منجـر بـه آشـنتخى روانشـناختى (كرانـت و همكاران، F +. .Y؛ اسجو كيت و همكاران، 199V) و ايجاد علائسم افسـرد گى و اضـطراب مسىشـود (اســـو كيت و هسلبروك، ع (994) و يافتها نيز حاكى از ايـن اسـت كـه مصرف كنند گان مواد نقصهايى را در مهارتهاى مقابله اى و اجتماعى دارند (مارلات و گردون، ·1911)، احتمـالاً آموزش مهارت هاى مقابلهى شناختى -رفتارى بـه بيمـاران

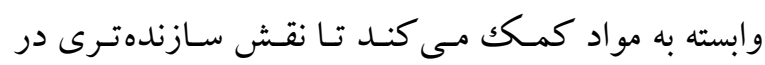
مديريت شرايط دشـوار و تسـلط بـر عوامـل تـنشزا ايفـا

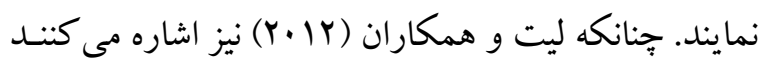

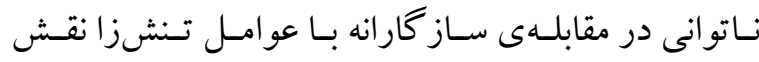
يررنكى در مصرف مشكل ساز مواد و الكل دارد، همجينين

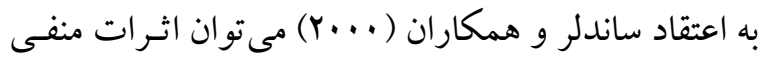

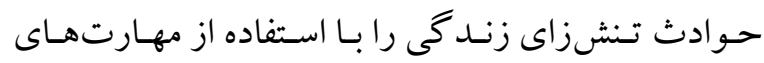
مقابلهاى مقتضى تعديل نمود، جر ا كه راهبردهـاى مقابلـه اى يكى از مهم ترين عناصـر سـلامت روانشـناختى بشـمار

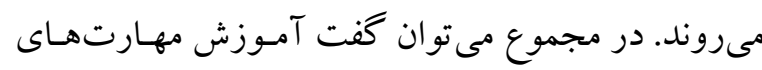

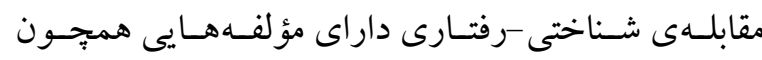
مهارت هاى خود آكاهى و افزايش عزت نفس است كـه از عناصر اصلى درمانهاى افسردگى بوده و به نظر مسىرسـد

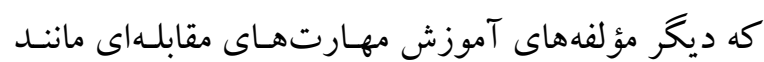
مهارتهاى مديريت هيجانات، روابط بين فردى، مهارتهاى ارتباط نيز مؤثر بوده و مىتواند بر شكايات فيزيكى مهى و برخاشخرى تأثير بحذارند. با توجه به اين كه در فرايند ذهن آكاهى تأكيـد اصـلى بـر بـر قـرار داشـتن در زمـان حسال و دركك مشـكلات و مسـائل
نتايج نشان مىدهد تفاوت معنىدارى بين ميـانكين نمـرات بس آزمون گروههاى آزمايشى (كروه آمـوزش مهارت-

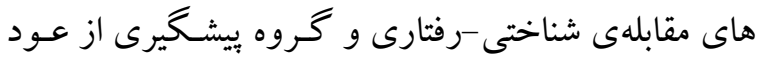

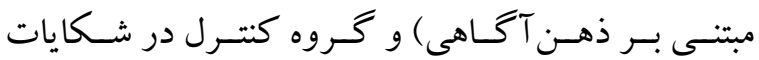

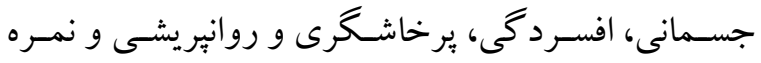
كلى علايسم روان شـناختى وجـود دارد. همجِنسين نتـايج حاصل از آزمون تعقيبى بنفرونسى حـاكى از ايـن بـود كـه كروههاى آزمايشى در ميزان اثربخشى بر كاهش شكايات

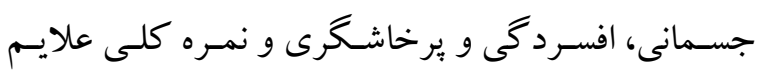

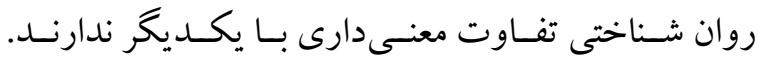

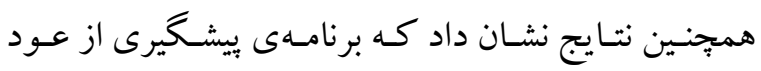
مبتنى بر ذهن آكَاهى در كـاهش رواني بريشى مـؤثر بـوده است اما آمـوزش مهارت هـاى شـناختى -رفتـارى در ايـن زمينـهـ تــأثير معنسى دارى نداشـته اسـت. مكانسـيم برنامـهـ آمسوزش مهـارتهـاى مقابلـهاى شـناختىرفتـارى بـه ايسن صورت است كه سطوح آكاهى افراد نسبت بـه مشكلات مرتبط با مسئله موجود، الكوى آن و راهبردهاى مقابله بـا آن را افزايش مسىدهـد كـه ايـن فراينــد از طريـق توضسيح روابط موجود بين افكار، احساسات و رفتار انجام مىشـود و در نهايت باعث دستيابى فرد بـه رويكـرد حـل مسـئلهى انطباقى مى گردد. يافتهاى بدست آمده بـا نتـايج هانـت و و

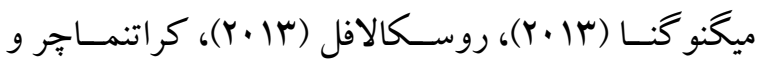

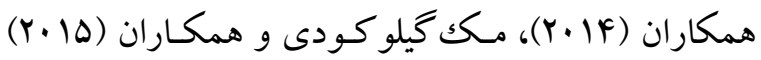
مبنى بر اثربخشى آموزش مهارتهـاى مقابلهاى شـناختى

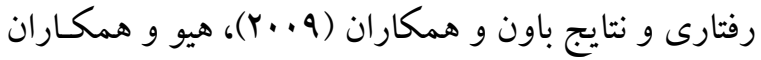

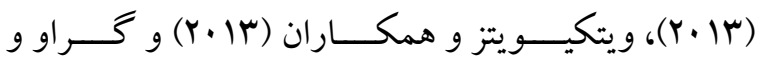

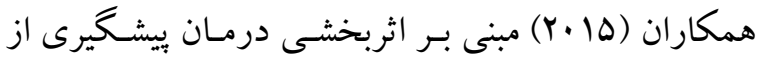

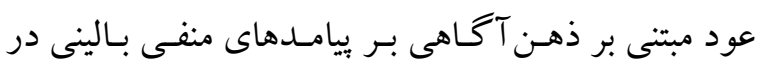

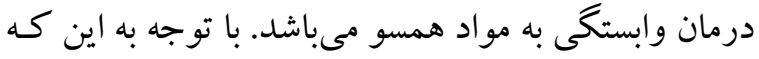


حالى است كه ييشخيرى از عود مبتنى بر ذهن آكاهى با

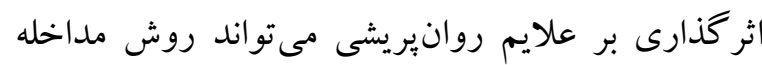

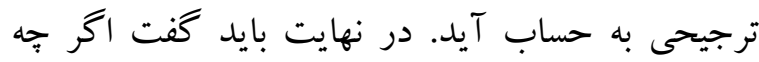
نتايج بدست آمده در اين بئوهش در راستاى نتايج مطالعات كذشته بود اما با اين حال بيان جنين نتايجى مستلزم ئزوهشهاى آتى بيشترى در اين زمينه مىباشد. جرا كه ئزوهش حاضر نيز مانند اغلب مطالعات آزمايشى با برخى محدوديتها از جمله عدم همسانى مواد مصرف شده توسط افراد و انجام هر دو روش آزمايشى توسط يكك نفر همراه بود. بنابر اين بيشنهاد مىشود بيزوهشهاى آتى به كنترل ماده مصرفى افراد توجه نمايند و براى برهيز از اثر ييشگويى خود كامبخش، آموزشهاى ارائه شده توسط افراد متفاوت انجام شود. نتايج اين مطالعه لزوم بكارگيرى روشهاى آموزش مهارتهاى مقابلهاى شناختى رفتارى و برنامه بيشخيرى از عود مبتنى بر ذهن آكاهى را به عنوان روشهاى مكمل درمان دارويیى در افراد تحت درمان وابستگى به مواد بيشنهاد مى كند.

\section{سياسگز ارى}

در يايان از تمام كسانى كه ما را در اجراى اين يخوهش يارى كردند، به ويثه مديريت محترم مركز ترك اعتياد

$$
\text { بامداد شهر اردبيل تشكر و قدردانى مىنماييم. }
$$

\section{References}

Bowen, S., Chawla, N., \& Marlatt, G.A. (2011). Mindfulness-based relapse prevention for addictive behaviors: a clinician $\mathrm{s}$ guide. Translated by Sajjad Basharpoor (1395), Ardabil: Publication of University of Mohaghwgh Ardabili.

Bowen, S., Chawla, N., Collins, S.E., Witkiewitz, K., Hsu, S., Grow, J.. \& Marlatt, A. (2009). Mindfulness-based relapse prevention for
بدون هر گونه تفسير يا قضاوت اسـت؛ در توصسيف نقـش فرايند ذهـن آكَاهى در كـاهش علائسم روانشـناختى بايـــ كفت ذهن آكَاهى با سلامت روانى ارتبـاط داشـته (نيل و

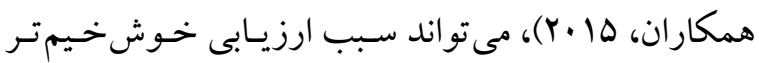

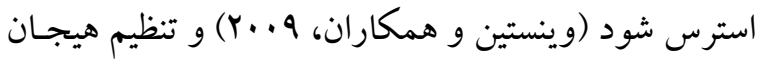
بهترى را به دنبال داشته باشد (كودال و همكاران، Y (Y). از ايـن رو مسىتـوان گفـت از آنجـايى كـه ذهـن آكـاهى مهـارتى شــاختى اسـتـ و فراينــدى ارادى، غير انفعـالى و

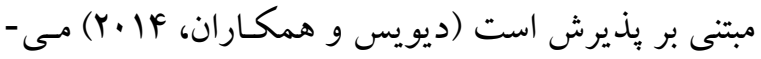
تواند نقش مـؤثرى در كـاهش علائسم افسـردگى بواســه

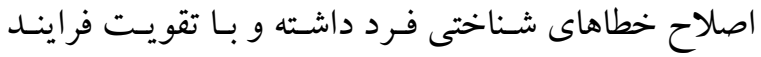
تنظيم هيجان كنترل يرخاشگرى را به دنبـال داشـته باشــا،

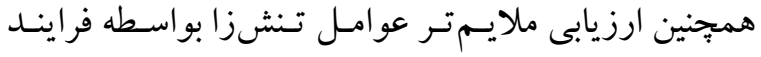
ذهن آكاهى مسىتوانـد كـاهش شـكايات جسـمانى فرد را منجر شود. در رابطه با كاهش علائم روانيريشسى بواسـهـ برنامه بيشخيرى از عود مبتنى بر ذهن آكاهى نيز بايد گفت

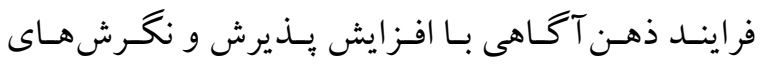
غيرقضـاوتى و كـاهش افكار خودكـار و واكسنش يـذيرى هيجانى مى تواند نقش بر رنكى در اين زمينه داشـته باشـد، جرا كه يذّيرش جنبه هاى غيرقابل قبول زنسد و كنترل صحيح افكار نادرست آشفتخى روانى كمترى را براى فرد وابسته به مواد به همر اه خواهد داشت و همجنـين كاهش عو اطـف منفسى و سـركوب افكار باعـث افزرايش سلامت روانى فرد مى گردد.

\section{نتيجه Fيرى}

در مجموع نتايج بدست آمده از اين مطالعه نشان داد كه آموزش مهارتهاى مقابله اى شناختى -رفتارى و برنامهى ييشخيرى از عود مبتنى بر ذهن آكاهى در كاهش علائم روانشناختى افراد وابسته به مواد تأثير مثبتى دارند اين در بر بر 
substance use disorders: A pilot efficacy trial. Substance Abuse, 30(4), 295-305.

Conway, K.P., Compton, W., Stinson, F.S., \& Grant, B.F. (2006). Lifetime comorbidity of DSM-IV mood and anxiety disorders and specific drug use disorders: results from the National Epidemiologic Survey on Alcohol and Related Conditions. Joumal of Clinical Psychiatry, 67, 247-257.

Deragotis, K.R, Lipman, R.S, \& Covi, L. (1973). SCL90-R outpatients psychiatric rating scale preliminary report. Psycho pharmalogy Bullsion, 9, 13-27.

Fergusson, D.M., Horwood, LJ., 1997. Early onset cannabis use and psychosocial adjustment in young adults. Addiction 92, 279-296.

Grant, B.F., Stinson, F.S., Dawson, D.A., Chou, S.P., Dufour, M.C., Compton, W., Pickering, R.P., \& Kaplan, K. (2004). Prevalence and co-occurrence of substance use disorders and independent mood and anxiety disorders: results from the National Epidemiological Survey on Alcohol and Related Conditions. Archives of General Psychiatry, 61, 807-816.

Green, K. M., Zebrak, K. A., Robertson, J. A., Fothergill, K. E., \& Ensminger, M. E. (2012). Interrelationship of substance use and psychological distress over the life course among a cohort of urban African Americans. Drug and Alcohol Dependence 123 (2012) 239- 248.

Groves, P., \& Farmer, R. (1994). Buddhism and Addictions. Addiction Research, 2(2), 183 194.

Grow, J. C. Collins, S.E. Harrop, E. N., Marlatt, G. A. (2015). Enactment of home practice following mindfulness-based relapse prevention and its association with substance-use outcomes. Addictive Behaviors, 40, 16-20.

Hill, C. L., \& Updegraff, J. A. (2012). Mindfulness and its relationship to emotional regulation. Emotion, 12(1), 81-90.

Hundt, NE1, Mignogna. J, Underhill. C., \& Cully, J.A. (2013). the relationship between use of CBT skills and depression treatment outcome: a theoretical and methodological review of the literature. Behavior Therapy, 44(1), 12-26.

Krattenmacher, T., Kühne, F., Führer, D., Beierlein, V., Brähler, E., Resch, F., Klitzing, K., Flechtner, H.H., Bergelt, C., Romer, G., \& Möller, B. (2013). Coping skills and mental health status in adolescents when a parent has cancer: A multicenter and multi-perspective study. Joumal of Psychosomatic ResearchVolume, 74(3), 252-259.

Litt, M.D., Kadden, R. M., \& Tennen, H. (2012). The Nature of Coping in Treatment for Marijuana Dependence: Latent Structure and Validation of the Coping Strategies Scale. Psychol Addict Behav. 26(4): 791-800.

Luthar, S.S., Cushing, G., 1997. Substance use and personal adjustment among disadvantaged teenagers: a six month prospective study. Joumal of Youth Adolescence, 26, 353-372.

Marlatt, G. A. (2002). Buddhist philosophy and the treatment of addictive behavior. Cognitive and Behavioral Practice, 9, 44-50.

Marlatt, G.A. (1984). George WH. Relapse prevention: introduction and overview of the model. British Joumal of Addiction, 79, 261-273.

Marlatt, GA.; Gordon, JR. (1980). Determinants of relapse: Implications for the maintenance of behavior change. In: Davidson, PDS., editor. Behavioral medicine: Changing health lifestyles. New York: Brunner/Mazel; 410452.

McGee, R., Williams, S., Poulton, R., Moffitt, T., 2000. A longitudinal study of cannabis use and mental health from adolescence to early adulthood. Addiction, 95, 491-503.

McGillicuddy, N. B., Rychtarik, R. G., \& Papandonatos, G. D. (2015). Skill training versus 12-step facilitation for parents of substance-abusing teens. Joumal of Substance Abuse Treatment, 50, 11-17.

Newcomb, M.D., Bentler, P.M., 1988. Impact of adolescent drug use and social support on problems of young adults: a longitudinal study. J. Abnorm. Psychol. 97,64-75.

Nila, K., Holt, D.V., Ditzen, B., \& Aguilar-Raab, C. (2016). Mindfulness-Based Stress Reduction 
(MBSR) enhances distress tolerance and resilience through changes in mindfulness. Mental Health \& Prevention, S22126570(15)30017-9.

Rus-Calafell, M., Gutiérez-Maldonado, J. OrtegaBravo, M., Ribas-Sabaté, J., \& Caqueo-Urízar, A. (2013). A brief cognitive-behavioural social skills training for stabilised outpatients with schizophrenia: A preliminary study. Schizophrenia Research, 143(2-3), 327-336.

Rychtarik, R.G., \& McGillicuddy, N.B. (2006). Preliminary Evaluation of a Coping Skills Training Program for Those with a Pathological-Gambling Partner. Joumal of Gamble Studies, 22:165-178.

Sandler, I. N., Braver, S., \& Gensheimer, L. (2000). Stress theory, research and action. In J. Rappaport \&E. Seidman(Eds.), Handbook of community psychology (pp. 187-213). New York: Kluwer Academic/Plenum.

Schuckit, M.A., Tipp, J.E., Bucholz, K.K. Numberger Jr., J.I, Hesselbrock, V.M., Crowe, R.R., Kramer, J. (1997). The lifetime rates of three major mood disorder and four major anxiety disorder in alcoholics and controls. Addiction 92, 1289 1304.

Schuckit, M.A., Hesselbrock, V.(1994). Alcohol dependence and anxiety disorders: what is the relationship? Am. J. Psychiatry 151, 17231734.

Suh, JJ. Ruffins, S., Robins, C.E., Albanese, M.J., Khantzian, EJ. (2008). Self-medication hypothesis: connecting affective experience and drug choice. Psychoanal. Psychol. 25, 518-532.

Swendsen, J.D., Tennen, H., Camey, M.A., Affleck, G., Willard, A., Hromi, A., 2000. Mood and alcohol consumption: an experience sampling test of self-medication hypothesis. Journal of Abnormal Psychology, 109, 198 204.

Teasdale, J. D., Segal, Z, \& Williams, J. M. (1995). How does cognitive therapy prevent depressive relapse and why should attentional control (mind fulness) training help? Behavior Research and Therapy, 33(1), 25-39.

Vieten, C., Astin, J. A., Buscemi, R., \& Galloway, G. P. (2010). Development of an acceptance-based coping intervention for alcohol dependence relapse prevention. Substance Abuse, 31, 108116.

Witkiewitz K, Bowen S, Douglas, H., \& Hsu, S. H. (2013). Mindfulness-Based Relapse Prevention for Substance Craving Addict Behav; 38(2), 1563-1571.

Witkiewitz, K., Marlatt, G. A., \& Walker, D. D. (2005). Mindfulness- based relapse prevention for alcohol use disorders. Journal of Cognitive Psychotherapy, 19, 211-228. 